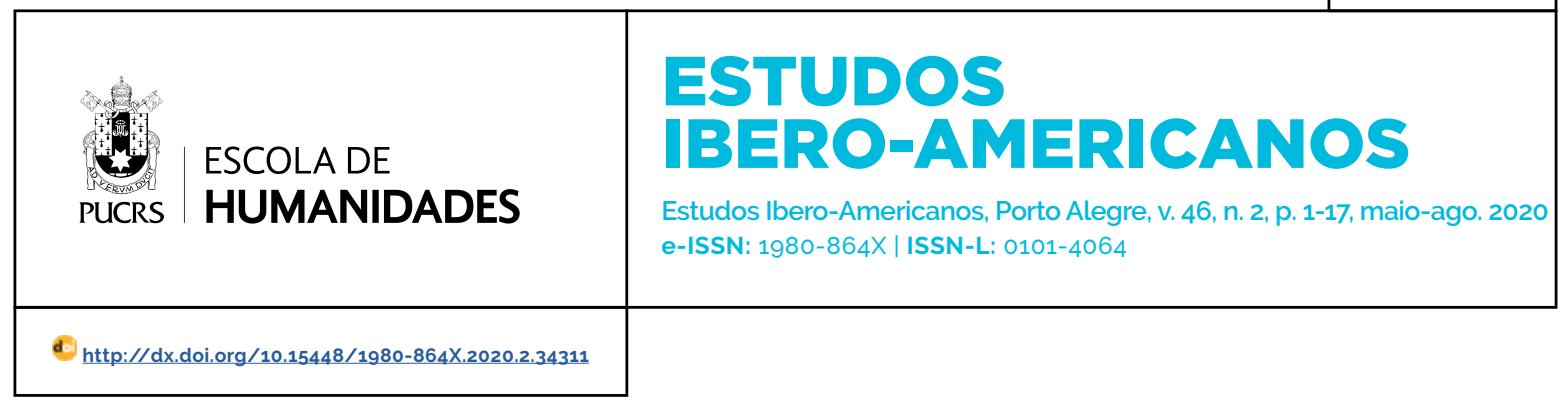

SEÇÃO: DOSSIÊ IMPRENSA, CULTURA E CIRCULAÇÃO DE IDEIAS

\title{
Inglaterra, França, Argentina: circulação de ideias na imprensa esportiva do Rio de Janeiro do século $\mathbf{X I X}^{\mathbf{1}}$
}

\author{
England, France, Argentina: ideas circulation in the 19th century Rio de Janeiro sporting press \\ Inglaterra, Francia, Argentina: circulación de ideas en la prensa deportiva de Río de \\ Janeiro del siglo XIX
}

\author{
Victor Andrade Melo ${ }^{2}$ \\ orcid.org/0000-0002-1983-1475 \\ victor.a.melo@uol.com.br
}

Recebido em: 1 jul. 2019. Aprovado em: 20 jan. 2020. Publicado em: 25 ago. 2020.
Resumo: O esporte, no decorrer do século XIX, foi uma das principais manifestações culturais difundidas pelos britânicos. Como era um costume importante no seu cotidiano, usualmente eles criaram clubes por onde se estabeleceram pelo mundo. A prática também se espraiou pelos navios de sua poderosa marinha (mercante e de guerra). Encarado como sinal de civilização e progresso, em cidades diversas se emulou o hábito, promovendo-se leituras próprias a partir dos limites materiais e peculiaridades culturais locais. Neste estudo, interessa-nos as apreensões sobre o que ocorria em outros países pelos que estavam envolvidos com a conformação do campo esportivo no Brasil, especialmente, os posicionamentos propalados pela imprensa fluminense. Temos em conta que, já no século XIX, jornais e revistas se tornaram importantes arenas públicas, fóruns de veiculação, embates e formação de opiniões. Assim, o objetivo deste artigo é discutir, nos periódicos esportivos publicados no Rio de Janeiro naquela centúria, a circulação de ideias sobre a prática oriundas da Inglaterra, França e Argentina, nações nas quais o campo estava melhor estruturado. Pelo seu perfil, especial atenção foi concedida à revista Semana Sportiva. A entabular esses esforços de investigação, procuramos lançar um olhar sobre nosso processo de adesão ao ideário e imaginário da modernidade.

Palavras-chave: História do Esporte. História da Imprensa. História do Rio de Janeiro.

Abstract: The sport, during the 19th century, was one of the main cultural manifestations worldwide spread by the British. As an important custom, it was usual to create clubs where they settled. The practice also spread out by the ships of his mighty navy (merchant and war). Faced as a sign of civilization and progress, in various cities the habit was emulated, since own readings that considered the material limits and cultural peculiarities. In this study, we are interested in the apprehensions about what happened in other countries by those who were involved with the conformation of the sporting field in Brazil, especially those positions that were spread by the press of Rio de Janeiro. We consider that, in 19th century, newspapers and magazines became important public arenas, forums for publicity, discussion and formation of opinions. Thus, the purpose of this article is to discuss, in the sporting periodicals published in Rio de Janeiro in that century, the circulation of ideas about sport from England, France and Argentina, nations in which the field was better structured. Because of its profile, special attention was given to Semana Sportiva magazine. In these research efforts, we try to take a look at our process of adherence to the ideals and imaginary of modernity.

Keywords: Sport History. Press History. Rio de Janeiro History.

Resumen: El deporte, a lo largo del siglo XIX, fue una de las principales manifestaciones culturales difundidas por los británicos. Como era costumbre importante en su cotidiano, era habitual crearen clubes donde se establecian por el mundo. La práctica también se expansionó por los buques de su poderosa marina (mercante y de guerra). Encarado como señal de civilización y progreso, en ciudades
Artigo está licenciado sob forma de uma licença Creative Commons Atribuição 4.0 Internacional. 
diversas se emuló el hábito, promocionándose lecturas propias a partir de los limites materiales y peculiaridades culturales locales. En este estudio, nos interesan las aprehensiones sobre lo que ocurría en otros paises por los que estaban involucrados con la conformación del campo deportivo en Brasil, especialmente aquellas posiciones que se difundieron por la prensa fluminense. Tenemos en cuenta que, ya en el siglo XIX, periódicos y revistas se convirtieron en importantes arenas públicas, foros de difusión, embates y formación de opiniones. Así, el objetivo de este artículo es discutir, en los periódicos deportivos publicados en Río de Janeiro en aquella centuria, la circulación de ideas sobre el deporte oriundas de Inglaterra, Francia y Argentina, naciones en las que el campo estaba mejor estructurado. Por su perfil, especial atención fue concedida a la revista Semana Sportiva. Con esos esfuerzos de investigación, buscamos fijarnos el nuestro proceso de adhesión al ideario e imaginario de la modernidad.

Palabras clave: História del Deporte. História de la Prensa. História de Rio de Janeiro.

\section{Introdução}

"Tudo quanto o esporte tem criado pelo mundo, temos nós por cá, com as tais modificações - em paródia. por assim dizer"

(Cidade do Rio, 11 dez. 1901, p. 1)

"Segunda feira, 30 do corrente, fazem-se carreiras na praia do Bota Fogo (pela manhã, às horas que permitir a maré) por prêmio de uma taça de prata do valor de 100000 réis; e logo depois, entrará quem quiser, n'outra carreira por prêmio de uma bolsa de ouro" (Gazeta do Rio de Janeiro, 25 maio 1814. p. 4): dessa forma, pela primeira vez uma prática esportiva foi anunciada nas páginas de um periódico brasileiro, a Gazeta do Rio de Janeiro, o pioneiro a ser redigido e publicado no País. Ainda que fosse um órgão da Coroa, mais destinado a comunicados do governo e a relatos de fatos internacionais, no jornal também se informava algo dos acontecimentos sociais da capital, entre as quais certas novidades que chegavam com a transferência da familia real portuguesa para o Brasil. ${ }^{3}$

Para ser preciso, não se tratou stricto sensu de uma iniciativa esportiva, já que o campo ainda não estava forjado em terras brasileiras. Foi uma manifestação primeva de uma prática que tardaria alguns anos para melhor se conformar (MELO, 2014), naquele momento organizada em função da maior presença de britânicos na cidade. Há que se ter em conta que uma cultura de divertimentos públicos vinha se delineando no Rio de Janeiro desde o quartel final do século XVIII, incrementada desde a chegada dos monarcas lusitanos (MELO, 2016).

É relevante considerar que os primeiros periódicos registraram informações e posicionamentos sobre diversas práticas de entretenimento, como as touradas (MELO, 2013, 2015) e o jogo da bola (MELO, 2016), bem como outras experiências com as corridas de cavalos (MELO, 2014). Esses eventos usualmente apareceram nas páginas da já citada Gazeta do Rio de Janeiro, do Império do Brasil: Diário Fluminense, do Diário do Rio de Janeiro e do o Spectador Brasileiro.

Esses registros se tornaram cada vez mais comuns no decorrer da segunda metade do século XIX. Deve-se ter em conta que, no Rio de Janeiro, se deu pari passu o desenvolvimento da imprensa e a conformação do campo esportivo, ambos relacionados a um conjunto similar de ocorrências. Atenderam a uma sociedade que foi assumindo discursos de adesão a ideais de civilização e progresso, marcada por uma diversificação dos negócios, maior vitalidade política, fortalecimento de relações com bens simbólicos e materiais oriundos da Europa, melhor estruturação urbana e configuração de uma vida pública mais intensa, inclusive em função do delineamento de um mercado de entretenimentos.

Melo (2012), se debruçando sobre a presença do esporte nos periódicos fluminenses do século XIX, observou que a imprensa progressivamente o noticiou "porque ele crescentemente tornou-se uma prática socialmente valorizada, e a prática também se tornou crescentemente valorizada porque foi progressivamente noticiada na imprensa" (2012, p. 50). Nesse sentido,

em grande medida, os sentidos e significados do esporte foram aqueles que os jornalistas negociaram, sempre a meio do caminho entre os interesses da empresa, os seus interesses próprios e o que consideravam interesses públicos (o que normalmente significava interesses de pequenos grupos ou setores), esferas que não poucas vezes se misturavam (MELO, 2012, p. 50).

3 Para mais informações, ver Silva (2007). 
Não surpreende, assim, que um dos passos primordiais do campo esportivo fluminense (e nacional), a criação do Clube de Corridas, em 1849, tenha sido noticiada nas páginas do Jornal do Commércio, um dos mais importantes da ocasião (MELO, 2012). Nas notícias veiculadas nos periódicos, se começou a "explicar" ao público do que se tratava a prática, suas peculiaridades, regras de funcionamento, modos de usar.

Assim, jornais e revistas, no que tange ao esporte, como ocorreu com outros temas e objetos, desempenharam um importante papel de agências mediadoras, difundindo para a população um conjunto de representações positivas, anunciando as realizações a fim de convocar o público, explicando as particularidades das modalidades, defendendo as reivindicações dos espectadores, solicitando aos governantes atenção para a prática.

Nesse sentido, há similaridades entre o que se passou no Rio de Janeiro do século XIX e na Londres do século XVIII, onde se estabeleceu pioneiramente uma imprensa esportiva, até mesmo por ser o local/ momento de estruturação do esporte enquanto fenômeno moderno. O primeiro periódico específico foi lançado em 1793 - Sporting Magazine, mas foi mesmo em 1852 que surgiu uma iniciativa de maior alcance, o Sportsman (HARVEY, 2013).

É relevante essa referência ao Reino Unido, pois de lá vieram importantes influências no que tange à conformação dos esportes no Rio de Janeiro, em alguns casos mediadas pela ação de clubes fundados por britânicos na cidade estabelecidos. Tratou-se de um processo de trânsito cultural, aqui entendido como postura ativa de apropriação de manifestações que têm origem em outros cenários (CANCLINI, 1997). Como sugere Melo (2017, p. 202):

No meio das ambiguidades típicas das agremiações de britânicos, fortalecidas por haver membros da colônia no Brasil nascidos, possibilitaram-se encontros que foram importantes na formação da cultura brasileira pela difusão de diferentes hábitos e costumes, entre os quais a prática esportiva.

O esporte, no decorrer do século XIX, foi uma das principais manifestações culturais difundidas pelos britânicos. Como era costume importante no seu cotidiano, inclusive no que tange a sua formação educacional (HOLT, 1989), usualmente criaram clubes por onde se estabeleceram pelo mundo. A prática também se espraiou pelos navios de sua poderosa marinha (mercante e de guerra). Encarado como sinal de civilização e progresso, em diversas cidades se emulou o hábito, promovendose leituras próprias a partir dos limites materiais e peculiaridades culturais locais.

Neste artigo, interessa-nos discutir as apreensões sobre o que ocorria em outros paises pelos que estavam envolvidos com o processo de conformação do campo esportivo no Brasil, especialmente, os posicionamentos propalados pela imprensa fluminense. Temos em conta que, já no século XIX, os periódicos se tornaram importantes arenas públicas, fóruns de veiculação, embates e formação de opiniões.

Trabalhamos com um perfil específico de publicação. Se, no decorrer daquela centúria, houve o aumento do trânsito de informações e de posicionamentos sobre o esporte nos jornais e revistas de temática geral, de maior ou menor circulação, a partir de certo momento, conforme a imprensa foi se aperfeiçoando, surgiram os periódicos esportivos.

No Rio de Janeiro, na década final do século XIX, se percebe o início, "mesmo que em bases precárias, (d)o processo da moderna comunicação de massa" (VELLOSO, 2006, p. 313), marcado, inclusive, por uma diversificação de títulos: "Ao lado das edições dos jornais diários proliferam revistas mundanas, [...], entre centenas de publicações" (BARBOSA, 2010, p. 118). É clara a maior conexão com as novidades mundiais, entre as quais se encontrava o esporte, especialmente com o que se passava na Europa e nos Estados Unidos (MARTINS, 2001; MARTINS; LUCA, 2008).

Assim, o objetivo deste artigo é discutir, nos periódicos esportivos publicados no Rio de Janeiro do século XIX, a circulação de ideias sobre o esporte oriundas da Inglaterra, ${ }^{4}$ França e Argentina, países nos quais o campo estava melhor estruturado. Pelo seu perfil, especial atenção foi concedida à publicação Semana Sportiva.

\footnotetext{
4 Neste artigo, usamos Inglaterra, ao invés de Reino Unido, para seguir a nomenclatura utilizada nos periódicos.
} 
Lançada em 1889, essa revista foi publicada até 1908, sempre com periodicidade semanal. Mais do que sua longevidade, destaca-se por sua abrangência, anunciando e discutindo as iniciativas de diversas modalidades em um momento em que se ampliava o interesse pelo esporte. Tendo em vista as restrições de acesso números desaparecidos ou não disponiveis para consulta - trabalhamos com 62 exemplares - do número 355 do ano X (14 out. 1899) ao número 417 do ano XII (29 dez. 1900). Para complementar a investigação, utilizamos notícias sobre seu perfil difundidas por outros periódicos.

Vale ressaltar que houve alguns jornais e revistas que, mesmo não sendo exclusivamente dedicados ao esporte, ao tema dedicaram atenção expressa inclusive no título. ${ }^{5}$ Não nos debruçamos sobre esse material, deixando sua investigação para outra ocasião. De toda forma, deve-se considerálos como mais um indicador do crescimento do interesse pela prática, bem como da multiplicação de iniciativas da imprensa brasileira.

Ao discutir a circulação de ideias ${ }^{6}$ na imprensa esportiva fluminense, procuramos lançar um olhar sobre nosso processo de adesão ao ideário e imaginário da modernidade, desvendar certas inspirações adotadas considerando que o esporte foi uma das manifestações mobilizadas com intuitos civilizatórios (MELO, 2001).

\section{Periódicos sportivos no Rio de Janeiro do século XIX}

O primeiro periódico exclusivamente dedicado ao esporte teve uma longa duração, mas uma difusão e uma cobertura restritas. A Revista da Sociedade Jockey-Club foi publicada entre 1868 , ano de fundação do clube, ${ }^{7}$ e 1879. O intuito era difundir informações sobre a agremiação. Nas suas páginas, encontram-se atas de reuniões, resultados financeiros e informes das provas organizadas, bem como alguns posicionamentos da diretoria. Como bem perceberam Santos e Giglio (2017, p. 5):

A publicação de uma revista oficial do clube era uma estratégia dos gestores para dar publicidade aos seus discursos a um público mais amplo. Esta revista nos ajuda a perceber o discurso proferido pelos gestores das organizações e o esforço da construção da imagem organizacional do clube para a sociedade. Tratava-se de um espaço para divulgar os ideais que os gestores clamavam serem os norteadores do clube.

É possivel que tenha se encerrado a publicação da revista por ela ter assumido a forma de relatório de diretoria, como já indicam os últimos números. De periodicidade anual, seus exemplares tinham tamanhos diversos, variando de 50 a mais de 200 páginas. Redigida por algum membro da direção, em geral não identificado, foi impressa em três importantes empresas: a Tipografia Americana (de João Juvêncio Ferreira de Aguiar, responsável pelo jornal A Nação), a Tipografia do Diário do Rio de Janeiro (que editava o noticioso de mesmo nome e obras literárias) e a Tipografia da Gazeta de Notícias (além do prestigioso periódico, lançou livros como o Ateneu, de Raul Pompéia). Aparentemente, não era vendida, sendo distribuída aos associados do Jockey Club.

O turfe foi um dos esportes que mais claramente se inspirou nos acontecimentos britânicos e franceses. Na Revista da Sociedade Jockey-Club, os posicionamentos da diretoria usualmente recorriam a exemplos desses países. Por exemplo, para ressaltar a importância da modalidade para o desenvolvimento da economia nacional em função das possiveis contribuições que poderia dar para o aperfeiçoamento da raça do equino brasileiro. Um cronista sugeriu que, por reconhecerem esse potencial, na Inglaterra e França, quem apoiava as corridas de cavalos eram "os reis, os príncipes, os fidalgos, os homens ricos e algumas corporações públicas e particulares"

\footnotetext{
5 O Boreas: sportivo, litterario e ilustrado (1890); O Binoculo: folha semanal, sportiva e teatral (1890); O Binoculo: folha bi-semanal sportiva e teatral (1891); O Frontão: jornal sportivo, litterario e teatral (1893); Petit Sport: semanario sportivo e theatral (1895); A Arena: jornal sportivo, litterario, humoristico e noticioso (1897); Vida Fluminense: periodico illustrado, litterario e sportivo (1889/1890).

6 Neste artigo, a noção de "circulação de ideias" não reitera a compreensão de que houve um caminho único "centro-periferia", como se apenas "copiássemos" o que vinha de países europeus. Buscamos entender a conexão de histórias que se deu por meio de reinterpretações e contatos múltiplos, na esteira do que aponta o já citado Nestor Canclini. Por isso, nos interessa perceber também o diálogo que se estabeleceu com a Argentina na construção de leituras dos cronistas brasileiros. Não aprofundaremos o debate conceitual em função das restrições de espaço. Para uma discussão sobre o tema, inclusive no que tange às diversas percepções teóricas, ver Maia (2019).

7 Para mais informações sobre o clube, ver Needell (1993), Melo (2001) e Santos (2015).
} 
(Revista da Sociedade Jockey-Club, 1870, p. 46). O intuito do narrador era incentivar elites e governo brasileiro a tomarem procedimento semelhante.

Esse investimento, segundo o cronista, ajudaria a entender por que a Inglaterra possuía alguns dos melhores cavalos do mundo (Revista da Sociedade Jockey-Club, 1871, p. 13). Por isso, o turfe seria tão valorizado por lá, sendo, na sua visão, "o desvelo e a glória da aristocracia" (Revista da Sociedade Jockey-Club, 1876, p. 107). Tratar-seia de um exemplo a animar os projetos do Jockey Clube fluminense. As experiências britânicas da modalidade eram também inspiração para o funcionamento cotidiano da agremiação, como na preparação dos códigos de corridas (Revista da Sociedade Jockey-Club, 1871, p. 48).

Mais do que circulação de ideias, percebe-se que havia intensa movimentação de cavalos e jóqueis vindos da Inglaterra, algo que foi usual na trajetória do turfe fluminense no século XIX. Eram múltiplos os negócios que cercavam essas iniciativas, algumas vezes, mesmo com polêmicas no que tange ao trânsito de documentação. ${ }^{8}$

Mesmo que a inspiração central fosse o que ocorria na França e na Inglaterra, reconhecidos por sua qualidade, muitos também foram os cavalos da Argentina que participavam das corridas fluminenses. ${ }^{9}$ Usualmente, a propósito, se comparou o que se passava por aqui com as iniciativas de agremiações platinas, em geral, sendo constatada a "distância que infelizmente ainda nos separa do clube de corridas de Buenos Aires" (Revista da Sociedade Jockey-Club, 1873, p. 27).

Deve-se considerar que o desenvolvimento do esporte naquele país, inclusive do turfe, teve forte relação com a grande colônia britânica por lá instalada, a maior da América Latina (HORA, 2014), uma influência que também se fez sentir na conformação do campo esportivo nacional (MELO, 2017), em bases menos intensas, todavia. Para além dessa relação com o mundo europeu, há que se ter em conta que, na Argentina, estimulouse o desenvolvimento da modalidade, um eficaz processo de criação de cavalos que se deu a partir da mescla de animais puro-sangue e crioulos, algo que no decorrer do tempo acabou sendo mesmo registrado como um traço identitário (ARCHETTI, 2003). O Hipódromo Argentino de Palermo, criado em 1876, foi, de fato, um dos mais importantes do continente. Em Buenos Aires, a modalidade se tornou rapidamente popular (HORA, 2014).

Outros "periódicos de clubes" foram lançados no século XIX. O mais notável deles foi o veículo oficial do principal concorrente do Jockey Clube, o Annuario das Estações Sportivas: Derby Club. A exemplo da outra revista, tratou-se de uma publicação anual exclusivamente dedicada às corridas de cavalos, cujo intuito era registrar tudo o que dizia respeito ao funcionamento da sociedade turfistica: decisões de diretoria, resultados, expectativas, gastos etc.

O Annuario era menos opinativo do que a revista do Jockey Club, também oferecido aos associados de forma gratuita, não sendo possivel saber a tipografia utilizada. Lançado em 1885, mesmo ano de fundação do Derby Club, ${ }^{10}$ manteve-se ativo durante todo seu tempo de existência, sendo sua última edição publicada em 1931. No ano seguinte, deu-se sua união com o outrora rival, originando o atual Jockey Club Brasileiro.

Com número bem variável de páginas, foi editado por mais de 40 anos (de 1885 a 1926) por um personagem importante, Manoel Valadão, dirigente do clube em várias ocasiões, organizador de muitas iniciativas, um dos principais memorialistas do turfe. Há que se destacar que o comerciante, industrial e dramaturgo foi figura de destaque na cidade. Somente por ter falecido, ${ }^{11}$ nas últimas edições do Annuario assumiu a responsabilidade Armando del Castillo. ${ }^{12}$

Vale ter em conta que, na transição das décadas

\footnotetext{
8 Ver, por exemplo, o relato sobre o cavalo Zephiro na Revista da Sociedade do Jockey-Club, 1872, p. 86. Para uma informação sobre um jóquei britânico, ver Revista da Sociedade do Jockey-Club, 1877, p. 15.

9 Ver, por exemplo, Programa das corridas de 1873, Revista da Sociedade do Jockey-Club, 1873, p. 17. Também participaram de páreos animais oriundos da França, Estados Unidos, África do Sul, entre outros.

10 Para mais informações sobre o clube, ver Melo (2001) e Santos (2015).

11 Por ocasião de seu falecimento, na edição de 1927, o Annuario publicou uma longa homenagem a Manoel Valadão (1927, p. 43).

12 Houve mais um "periódico de clube" no século XIX, ao que parece uma breve iniciativa de uma importante agremiação da cidade: 0 Boa Noite: periódico da Real Sociedade Club Gymnastico Portuguez. Lançado em 1894, só há disponivel um número de quatro páginas, o que nos impede de saber se teve continuidade e alcance.
} 
de 1880-1890, muitos foram os hipódromos/ clubes a funcionar no Rio de Janeiro. Além dos já citados Jockey Club e Derby Club, houve ainda o Turf Club, o Hipódromo Nacional e o Prado Guarany, bem como o Hipódromo Guanabara que, localizado em Niterói, também atraia público da capital do Império/República. As corridas de cavalos tornaram-se um dos principais assuntos da cidade, não surpreendendo que muitos periódicos the devotassem atenção (MELO, 2001).

Um exemplo interessante é O Sportman, publicado semanalmente em 1887, ${ }^{13}$ dirigido por J. de Montargis. ${ }^{14}$ Encontrado em estabelecimentos espalhados pelo Centro, Vila Isabel e Tijuca, era vendido a 100 réis, um preço acessivel ao grande público e usual entre os periódicos da ocasião.

Ajudava a viabilizar a publicação, a inserção de anúncios dos eventos de clubes de turfe (todos em funcionamento) e remo (especialmente do Clube de Regatas Cajuense), bem como de empresas que ofereciam serviços/produtos ligados à modalidade (como a Antiga Casa Moraud, especializada em ferraduras, alfafa, feno e aveia, bem como no cuidado de animais)
(O Sportman, 11 jun. 1887, p. 3) ou de firmas que buscavam relação simbólica com os hábitos dos sportmen (caso da Cerveja A. Drehers e do Toillet Club, estabelecimento que oferecia uma sala de fumar, um restaurante, um estande de tiro e um salão de beleza) (O Sportman, 11 jun. 1887, p. 3).

A imagem que identificava o periódico fazia referências a várias modalidades, inclusive ao remo, mas o interesse central era mesmo o turfe. Ainda que noticias e anúncios de regatas também fossem veiculados, o Sportman se propunha a não só contribuir com a difusão das corridas de cavalos, como também com a defesa dos interesses dos clubes.

Esse modelo de capa - que se tornaria usual nos periódicos esportivos do Rio de Janeiro, era claramente inspirado em similares europeus e norteamericanos. Desde o pioneiro Sporting Magazine, era comum a apresentação desse "programa" da revista, bem como o uso de gravuras para ilustrar as matérias, algo que somente começou a decrescer com a vulgarização da utilização de fotografias, na capital brasileira mais identificável a partir da transição dos séculos XIX e XX (MAUAD, 2005).

Imagem 1 - Extrato da capa de O Sportman

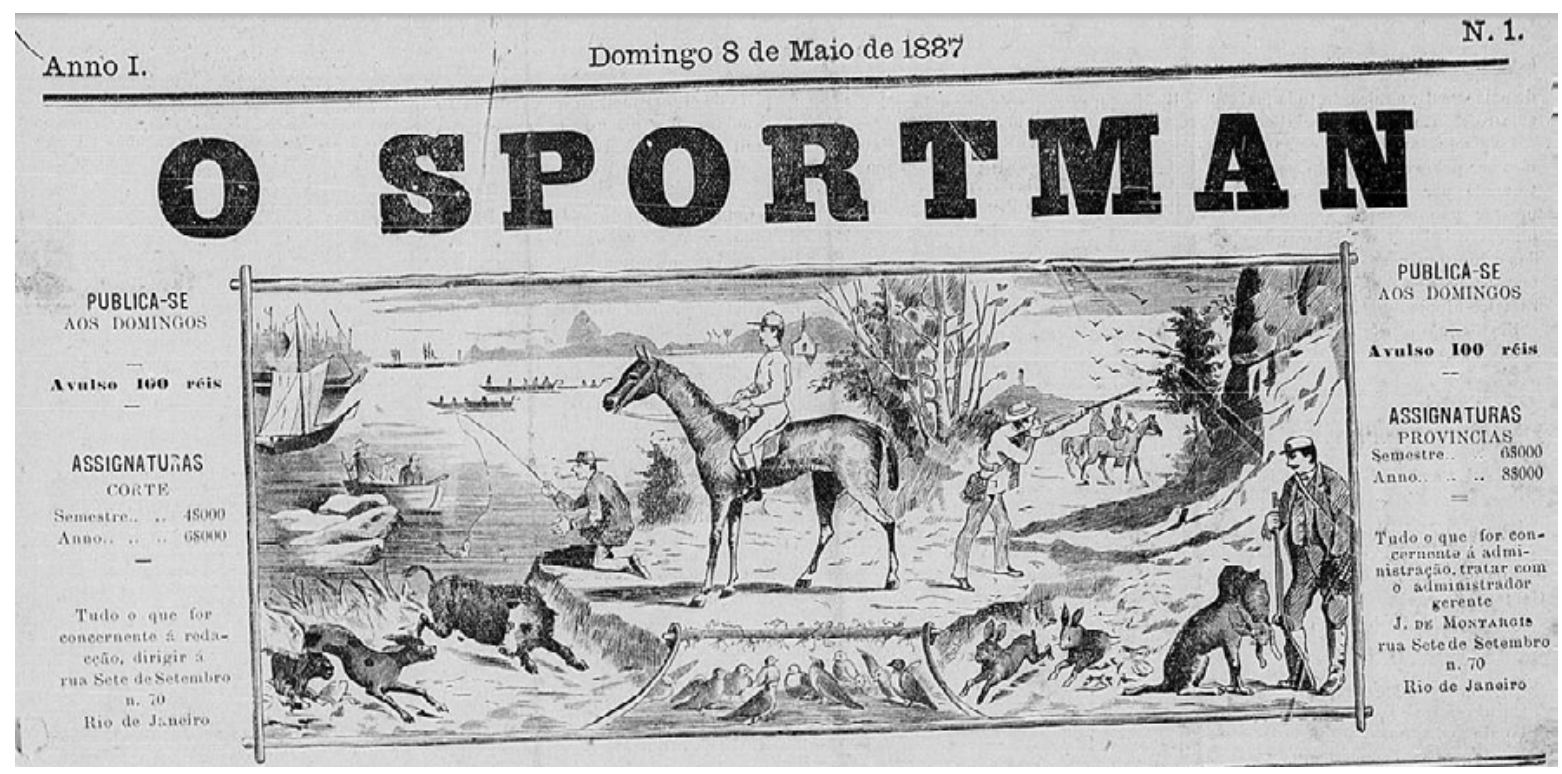

Fonte: O Sportman, 8 maio 1887, p. 1.

13 Há disponíveis 22 números de quatro páginas. Temos indícios de que foi publicado pelo menos até o final de 1887 (citações no periódico O Sport dos meses de novembro e dezembro daquele ano).

${ }_{14}$ A partir do $3 .^{\circ}$ número, passou a ser apresentado como J. de Mesquita. Não sabemos se houve mudança de gerência, se era um pseudônimo ou o mesmo personagem que "nacionalizara" seu nome, algo comum entre os estrangeiros no século XIX. Mesquita era um conhecido turfista, criador e importador de cavalos. 
No caso de O Sportman, destaca-se a adaptação de um imaginário internacional à cidade, com a Baía de Guanabara e o Pão de Açúcar ao fundo (Imagem 1). Mesmo sutil, não se deve desprezar a iniciativa como um esforço de leitura local, de busca de ambientação das modalidades a referências espaciais fluminenses.

A veiculação de informações do continente europeu foi constante no periódico, usualmente mobilizadas para sugerir que o turfe era mais do que mera diversão; tratar-se-ia de uma potencial contribuição para o progresso da nação. Assim, uma notícia sobre a eleição de uma nova diretoria do Jockey Club de Paris foi encarada como uma ocasião para demonstrar "a ideia que na culta Europa se faz das sociedades promotoras de melhoramentos da raça de cavalar" (O Sportman, 15 maio 1887, p. 1).

Como na revista do Jockey Club, os informes do exterior, especialmente, da Inglaterra e da França, ${ }^{15}$ indicavam também supostos caminhos pelos quais deveria trilhar o turfe brasileiro. Uma decisão tomada pelas diretorias dos nossos clubes era contrastada com o que ocorria naqueles paises. ${ }^{16}$ o Sportman, assim, ao mesmo tempo em que divulgava e incentivava a modalidade, também criticava e apontava saídas para sua consolidação.

Da mesma forma, essa circulação de ideias promovia uma conexão simbólica do que ocorria no Brasil com o que se passava no mundo, como se a integrar as iniciativas fluminenses em um quadro internacional da modalidade. Essa postura repercutia e reforçava a ideia de que os eventos de turfe eram uma emulação de um costume valorizado em cidades consideradas mais desenvolvidas, sendo, portanto, expressão e contributo para o processo civilizatório nacional.

Há que se ter em conta que o momento de publicação desse e de outros periódicos foi marcado pela crise da monarquia nacional, que resultaria na transição para a República. Ainda vigorava, contudo, uma ideia de que o País poderia ser uma civilização à moda europeia nos trópicos, parâmetro que vinha sendo construido em todo o reinado de Pedro II (SCHWARCZ, 1998).

A propósito, entre as notícias sobre as provas e cotidiano dos clubes brasileiros, do Rio de Janeiro e de outras cidades (em geral na coluna "Interior"), em várias ocasiões se anunciou a já citada importação de cavalos e jóqueis. Essa longa citação indica o forte relacionamento estabelecido com o turfe de países onde a prática estava mais consolidada, inclusive a manutenção da já citada relação com a Argentina:

\begin{abstract}
O número de animais de sangue puro importados da França e da Inglaterra, ultimamente. tem sido tão crescido e de tal escolha [...] que, sem receio da menor contestação, se pode asseverar que em futuro muito próximo as corridas de cavalos da capital do Império serão não só as mais luzidas da América Meridional, senão também dignas de ombrear com as de alguns paises da Velha Europa. Acresce [...] que um rico amador das margens do Prata [...] vai mandar vir dali os seus excelentes animais de raça para correrem nos nossos prados $(O$ Sportman, 22 maio 1887, p. 1).
\end{abstract}

Segundo essa concepção, a importação de modelos e de produtos alçaria o turfe brasileiro a um patamar superior. Essa inspiração também se identifica em outro periódico que parece ter tido menos repercussão do que O Sportman. Lançado no mesmo ano de 1887, o sport: órgão dos interesses do povo, de periodicidade semanal, tinha como proprietário A. F. Reynaud ${ }^{17}$ e dedicava atenção quase exclusiva ao turfe (poucas foram as noticias de ciclismo e regatas).

Somente há disponiveis quatro números de quatro páginas desse periódico. É possivel perceber, mesmo assim, que se tratou de uma empreitada com certa estruturação. Logo no seu primeiro exemplar, anunciou-se que tinha agências em Paris, Buenos Aires, Londres e Nova York. Vendido a 100 réis, como O Sportman também oferecia assinatura para a Corte e Províncias. Informava já

\footnotetext{
15 Havia uma coluna denominada "O sport no estrangeiro", mas as notícias sobre o que ocorria no exterior a ela não se resumiam, se espraiando em diversas seções.

16 Isso foi muito comum no que tange ao código de corridas. Ver, por exemplo, o Sportman, 28 maio 1887 , p. 1.

17 Proprietário de uma tipografia localizada na Rua da Assembleia, também foi responsável por outras publicações, como 0 Brazil Elegante, uma revista de modas. Era proprietário de uma livraria especializada em romances. Foi representante de jornais e revistas francesas, por ele vendidas na cidade, bem como editor de hebdomadários dedicados aos franceses no nosso país estabelecidos. Assumia, assim, ser um mediador entre o Rio de Janeiro e o valorizado mundo europeu. Sobre o tema, ver Ferreira (2011).
} 
na capa, atitude rara entre os jornais e as revistas, que cobrava 100 réis por linha de propaganda.

o sport era mais crítico aos clubes de corrida, especialmente, combatendo as fraudes que, a seu ver, maculavam os principios mais nobres do esporte. ${ }^{18} \mathrm{O}$ periódico, portanto, se propunha a ser defensor dos espectadores. Tal enfoque ficava claro já no título: "órgão dos interesses do povo" (ver Imagem 2). O símbolo da revista, aliás, era uma águia carregando uma faixa em que se lia a expressão latina "pluribus unum" ("entre muitos, um"), embaixo havendo o dito "a união faz a força".

Imagem 2 - Extrato da capa de O Sport

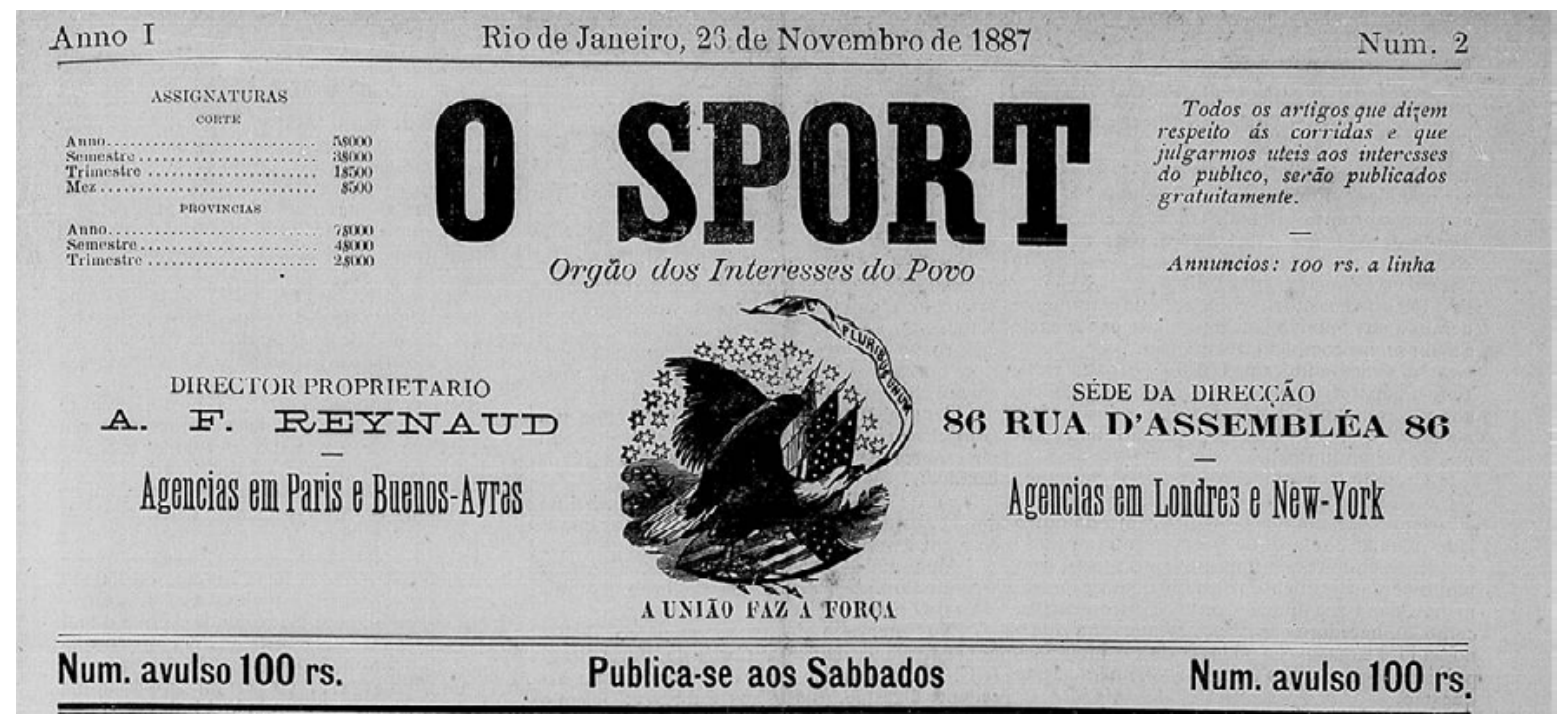

Fonte: O Sport, 26 nov. 1887, p. 1.

Conclamando o leitor a se posicionar, informavase na capa: "Todos os artigos que dizem respeito às corridas e que julgarmos úteis aos interesses públicos serão publicados gratuitamente" (O Sport, 19 nov. 1887, p. 1). Mais ainda, desde o seu primeiro editorial, constantemente criticou O Sportman por não ser contundente em suas considerações sobre o turfe, dispondo-se, portanto, a assumir tal papel. No fundo, tratava-se, aparentemente, menos de uma discordância de opiniões e mais de uma questão de mercado, de disputa de leitores.

A despeito desse perfil anunciado e efetivamente implementado, suas colunas também divulgavam o que se passava no turfe fluminense, nacional e internacional. O contato com o exterior parecia mesmo estabelecido mais amiúde, provavelmente em função de seus correspondentes, parte dos contatos transatlânticos de Reynaud. Sua vinculação normativa ao que vinha de Inglaterra e França era semelhante ao identificado em O Sportman. $\mathrm{Na}$ verdade, os formatos dos dois periódicos guardam muitas semelhanças.

O grande interesse pelo turfe pode ser sentido com o lançamento de outros periódicos de menor duração e sofisticação. Um deles foi $A$ Vida Sportiva: órgão dos interesses do turfe brasileiro, lançado em 1889. Publicado pela Imprensa Mont'Alverne, parecia mais destinado a defender os interesses das coudelarias. ${ }^{19}$

Um de seus diferenciais, outra inspiração do que supostamente se passava no continente europeu, foi dar mais atenção aos jóqueis, exaltando suas virtudes e vitórias, ao contrário dos outros periódicos que se dedicavam mais a criticar seu envolvimento em armações ou seu mau desempenho. Dessa maneira, por exemplo, se encerrou uma matéria de página inteira sobre um dos condutores: "Francisco

\footnotetext{
18 O periódico, todavia, acabou se envolvendo numa polêmica por ter se proposto a também acolher apostas, desagradando bookmakers e outros jornais/revistas. Ver, por exemplo, O Sport, 10 dez. 1887, p. 1.

19 Ver o editorial de A Vida Sportiva, 1 jun. 1889, p. 3. Como somente temos disponivel um exemplar de 16 páginas, não conseguimos saber muitas informações sobre esse periódico.
} 
Luiz tem por si as simpatias e as de todos os que com ele privam porque ele, além de seu um bom jóquei, é um cavalheiro delicado" (A Vida Sportiva, 1 jun. 1889, p. 4).

Vale observar que foi anunciada a fundação do "Club dos Archers Brazileiros" com o suposto fim de "elevar e moralizar a classe dos jóqueis" (A Vida Sportiva, 1 jun. 1889, p. 15). Começava a se construir uma representação positiva dos "atletas", não somente dos cavalos vencedores, algo que se tornaria mais usual com o remo a partir da transição de séculos.

Na última década do século XIX, no Rio de Janeiro, houve outros periódicos dedicados a diferentes modalidades. ${ }^{20}$ Como não há deles exemplares disponiveis para consulta, não foi possivel uma análise de seus perfis. Optamos por registrar seus títulos como mais um sinal do crescente interesse pelo esporte.

Em 1896, foi lançado O Bicyclo: semanário sportivo dedicado a velocipedia. Impresso na Tipografia Cardoso, de periodicidade semanal, tinha como redator Aurelio D’Aguiar. Já $O$ Remo debruçava-se sobre o esporte náutico. Hebdomadário, circulou no ano de 1899. Ambos são uma expressão do crescimento da popularidade das duas modalidades naquele fim de século.

Naquela década, também surgiram periódicos que se pretendiam multiesportivos, abordando efetivamente maior número de modalidades. Identificamos quatro que, infelizmente, não estão disponiveis para consulta: o Brazil Sportivo foi lançado em 1892, sendo proprietário I. Drummond Junior; redigido por L. A. Cardoso Braga, Chronica Sportiva foi publicado, com periodicidade semanal, em 1894; já Gentleman: periodico sportivo, cujo redator era A. de St. Albin, chegou às bancas em 1895; o hebdomadário Brazil Sport circulou em 1898, tendo Ed. Pacheco como protagonista.

Semana Sportiva foi mais um periódico que integrou esse significativo conjunto de iniciativas de imprensa. Pelo seu perfil, previamente apresentado na introdução, e pela disponibilidade de bom número de exemplares, resolvemos investigá-lo mais profundamente para lançar um olhar sobre a circulação de ideias acerca do fenômeno esportivo.

\section{Semana Sportiva: perfil e circulação de ideias}

Desde que foi lançado, em 1889, o redatorproprietário de Semana Sportiva foi um importante nome da imprensa fluminense, Henrique Blatter. Em A Vida Fluminense, uma caricatura assim o apresentava:

\begin{abstract}
Há quem o chame Henrique Bertin, um anúncio vivo digo que ele é. Não pensa em outra coisa. Quando o virem a correr, rua do Ouvidor abaixo, azafamado, suando, suando, não tem que ver: vai em busca de um anúncio para $O$ $P_{a i z^{21}}$, a folha de maior circulação da América do Sul; para a Vida Fluminense, o semanário mais bem desenhado das duas Américas: para a Semana Sportiva, única do gênero no país e fora dele; para o Tam-Tam, o periódico mais endiabrado do mundo inteiro. E quando não the querem dar o anúncio, de tais artes e manhas se serve que, afinal, saca-o! (Vida Fluminense, 17 nov. 1889, p. 8).
\end{abstract}

Blatter era mais do que um cronista, era um homem de negócios da imprensa, admirado por muitos por tal envolvimento. ${ }^{22}$ Ao contrário dos editores de outros periódicos, não era exatamente um turfista. Atento aos movimentos da sociedade fluminense, se envolveu com e lançou diferentes títulos, ${ }^{23}$ conhecendo bem o mecanismo de sua manutenção. A Semana Sportiva nasceu, assim, mais profissional pelas mãos desse destacado personagem que ficou à frente do projeto até o seu falecimento, em 1901. ${ }^{24}$

Um dos primeiros distribuidores do periódico foi Caetano Segreto, membro de uma familia envolvida com o ramo do entretenimento, responsável pela divulgação de cerca de 50

\footnotetext{
20 Registre-se que, na Bahia, em 1889, houve O Sport: periódico dedicado aos dignos turfistas desta capital. Em Recife, em 1895. fo lançado O Sport. Em São Paulo, foram ainda publicados o São Paulo Sportivo e A Bicycleta: semanário cyclistico ilustrado, ambos de 1896 ${ }_{21}$ Foi redator esportivo desse periódico, bem como de Vida Fluminense.

22 Sobre a vida de Blatter, ver Gazeta da Tarde, 10 abr. 1901, p. 1.

23 Entre os quais, O Século, A Noticia e O Tempo.

24 Com a morte de Blatter, anunciada em todos os jornais, seus herdeiros mantiveram a publicação, que passou a ser dirigida por Dario Villalba Alvim e Paulo Afonso Rodrigues (Almanak Laemmert, 1902, p. 1619).
} 
publicações (Novidades, 28 set. 1890, p. 2). Percebe-se que muitos foram os colaboradores na redação, poucos possiveis de identificar, pois a maioria fazia uso de pseudônimos. Pelo tom das matérias, pode-se sugerir que era gente que conhecia as modalidades e tinha alguma inserção no campo esportivo.

O periódico era impresso em tipografia própria (Almanak Laemmert, 1891, p. 393), junto com a secretaria e a redação localizadas na Rua da Imperatriz (antiga Rua do Valongo, atual Rua Camerino), um logradouro que fora local de comércio de escravos e foi se transformando em sítio de importantes negócios. Posteriormente, o escritório transferiu-se para a Rua do Ouvidor, no tempo em que passou momentaneamente a chamar-se Moreira César (Almanak Laemmert.
1898, p. 1548), se inserindo ainda mais no centro dos acontecimentos da capital.

Como dito, só conseguimos acessar o periódico a partir do mês de outubro de 1899 . já em seu $355^{\circ}$ número, $10 .^{\circ}$ ano. A imagemsímbolo das capas provavelmente era a mesma desde a origem do hebdomadário (ver Imagem 3). Também inspirada em periódicos europeus, percebe-se que as referências se prendem ao turfe, o que indica a já citada popularidade da modalidade no momento em que foi lançado, talvez até mesmo que, no início, as corridas de cavalos tenham sido o tema prioritário. O valor de venda seguia acessivel, os mesmos \$100 possivelmente cobrados desde 1889 (a ter em conta o preço dos outros periódicos esportivos).

Imagem 3 - Extrato da capa de Semana Sportiva

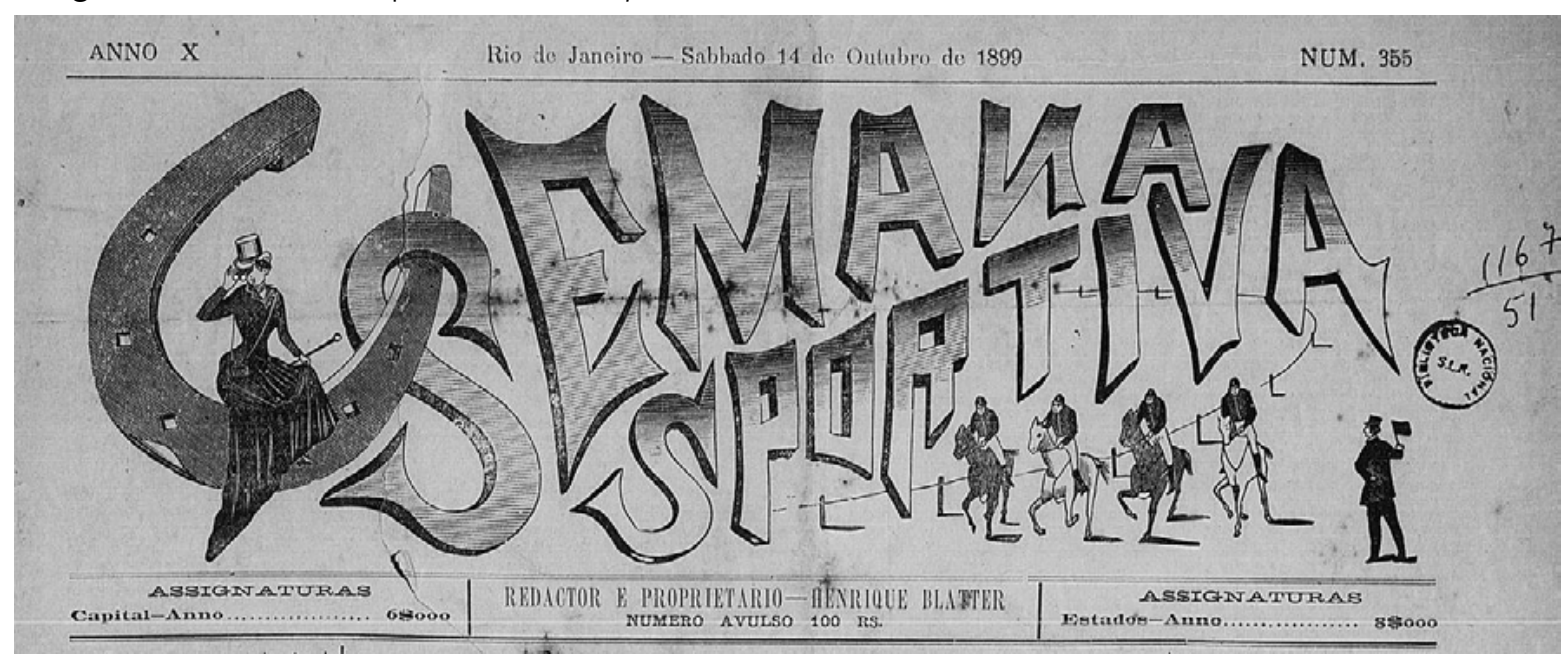

Fonte: Semana Sportiva, 14 out. 1899, p. 1.

Se boa parte das matérias ainda eram dedicadas ao turfe, destaca-se que, no primeiro número consultado, as duas imagens da capa sejam de Dario Cunha e Octavio Mafra, dirigentes do Clube de Regatas Icaraí, protagonistas nas iniciativas náuticas daquele fin de siècle. Essas fotografias chamavam atenção para a seção "Yachting", na qual se narravam as notícias do remo no Rio de Janeiro e no exterior (Inglaterra, França e Argentina), bem como dava-se destaque para os dirigentes e atletas em um momento em que essa modalidade tornava-se mais populare crescentemente estruturada, inclusive em função do surgimento de muitas agremiações e de ligas que lutavam pelo apoio e melhor organização do esporte. ${ }^{25} \mathrm{Na}$ verdade, essa prática bem se ajustou ao processo de adesão ao ideário e imaginário que se exponenciara na transição de séculos, chamando atenção de lideranças politicas e intelectuais (MELO, 2001).

Duas outras modalidades tinham colunas fixas, nas quais se seguia o mesmo modelo de se

25 Em 1895, foi criada a União de Regatas Fluminense, renomeada para Conselho Superior de Regatas (1900) e, posteriormente, para Federação Brasileira de Sociedades de Remo (a partir de 1902). 
informar notícias de competições e cotidiano das iniciativas, bem como se destacar os principais personagens. A velocipedia (ciclismo) e o jogo de pelotas (pelota basca) tornaram-se populares na transição de séculos, mas também motivos costumeiros de polêmica.

O que ocorre é que sua principal forma de organização não eram os clubes amadores, mas sim empresas que tinham em conta lucrar com o resultado da venda de entradas e poules (bilhetes de apostas). Não poucas vezes equívocos ou armação de resultados inflamaram o público que adotou comportamentos turbulentos, preocupando os responsáveis pela segurança pública e maculando uma ideia de sportman que algumas lideranças pretendiam consolidar (MELO; PERES, 2016).

Na verdade, muitos periódicos eram ambiguos no que tange às apostas. De um lado, criticavam a perda de caráter esportivo em função dos interesses do jogo de azar. De outro lado, as defendiam como alternativa para a manutenção das iniciativas. Semana Sportiva chegou a anunciar os resultados do jogo do bicho, na coluna "O bichinho", mesmo reconhecendo que a polícia seguia tentando coibir o costume que já se espraiara pela cidade.

De toda forma, a revista procurava também chamar atenção para os clubes de ciclismo e de jogos de pelotas, os inserindo nas iniciativas de desenvolvimento do esporte na capital federal. No caso do primeiro, a maior parte de notícias do exterior vinha da França, onde a modalidade já estava melhor estruturada e se apresentava como uma das favoritas da população (SCHETINO, 2008).

Naquele país, na transição de séculos, já havia algumas importantes provas de ciclismo, entre as quais a Paris - Roubaix e a Bordeaux - Paris, criadas pelo L'Velo, uns dos primeiros jornais esportivos franceses, majoritariamente dedicado ao ciclismo. Notícias desses eventos foram usualmente publicadas nas páginas da Semana Sportiva. ${ }^{26}$ Como usual em outras iniciativas, tais informações, de um lado, procuravam animar o desenvolvimento do esporte nacional, enquanto, de outro, eram usadas como exemplo de nossos limites que precisavam ser superados.

Outras modalidades, eventualmente obtinham espaço nas páginas da revista, especialmente, a natação e as corridas a pé, primórdios do atletismo. No caso dessas práticas, se exaltava mais fortemente as performances humanas, o fato de que eram esportes nos quais o atleta dependia basicamente de seu corpo.

Sobre o turfe, seguiram sendo publicadas notícias dos páreos e do cotidiano de clubes e coudelarias, iniciativas das agremiações fluminenses, mas também de outros estados e paises, da Inglaterra e da França, especialmente da Argentina, de onde veio o maior número de informações, para as quais havia mesmo uma coluna - "Cartas de Buenos-Aires". 27 Em algumas edições, houve a seção "Pelo exterior". Alguns editoriais foram dedicados a descrever as características da modalidade nessas nações. ${ }^{28}$

O periódico declarava ter colaboradores no exterior, embora não tenha sido possivel saber todos os nomes. Na Argentina, percebemos que atuavam Augusto A. Proasi e J. de Mesquita, como vimos antigo diretor de O Sportman. Havia ainda um certo "Gordo", provavelmente Carlos Coutinho, negociante que, estabelecido em Buenos Aires, trazia cavalos de lá para vender no Brasil. ${ }^{29}$

Completava cada edição um conjunto de propagandas de eventos esportivos, de produtos ligados ao esporte ou de empresas que apenas aproveitavam o espaço para se vincular aos sentidos e significados da prática. Esse recurso já vinha sendo usualmente utilizado para garantir a viabilidade financeira dos periódicos e Blatter, como vimos, parecia manejar com maestria tal

\footnotetext{
26 Ver, por exemplo, Semana Sportiva, 6 jan. 1900, p. 1.

27 Chegaram a ser anunciados com detalhes e imagens os principais eventos do turfe argentino, como o Grande Prêmio de Buenos Aires. Nessa ocasião, Semana Sportiva contou com a ajuda de um importante periódico daquele país, Caras y Caretas, com quem mantinha laços de colaboração (Semana Sportiva, 17 nov. 1900, p. 1). Sobre a revista da Argentina, ver Gamarnik (2018).

28 Alguns exemplos: "Turfe Francês" (Semana Sportiva, 27 jan. 1900, p. 1), "As provas inglesas" (Semana Sportiva, 2 jun. 1900, p. 1) e "Sociedade Hipica Argentina" (Semana Sportiva, 8 dez. 1900, p. 1)

29. Além das matérias que enviava, vale ver suas entrevistas publicadas em Semana Sportiva, 10 fev. 1900, p. 1 e Semana Sportiva, 24 mar. 1900, p. 1.
} 
possibilidade, o que também ajuda a entender a longevidade da iniciativa.

Semana Sportiva não se constituiu em uma ruptura com os parâmetros da imprensa esportiva do século XIX, mas, sintonizada com as mudanças dos padrões dos periódicos fluminenses daquela transição de centúrias, implementou algumas inovações dignas de registro: a) maior cuidado gráfico, inclusive com o uso constante de fotografias; b) aprimoramento da redação das notícias; e c) ampliação das modalidades cobertas. Tinha em conta, ao se inspirar no que se passava no campo esportivo mundial e em sua própria trajetória, conectar os "esportes antigos", de caracteristicas mais aristocratas, com os "esportes modernos", de perfil mais burguês, como bem expresso em caricatura no ano de 1899 (Imagem 4).

Imagem 4 - Caricatura no Semana Sportiva Comparação de perfis esportivos

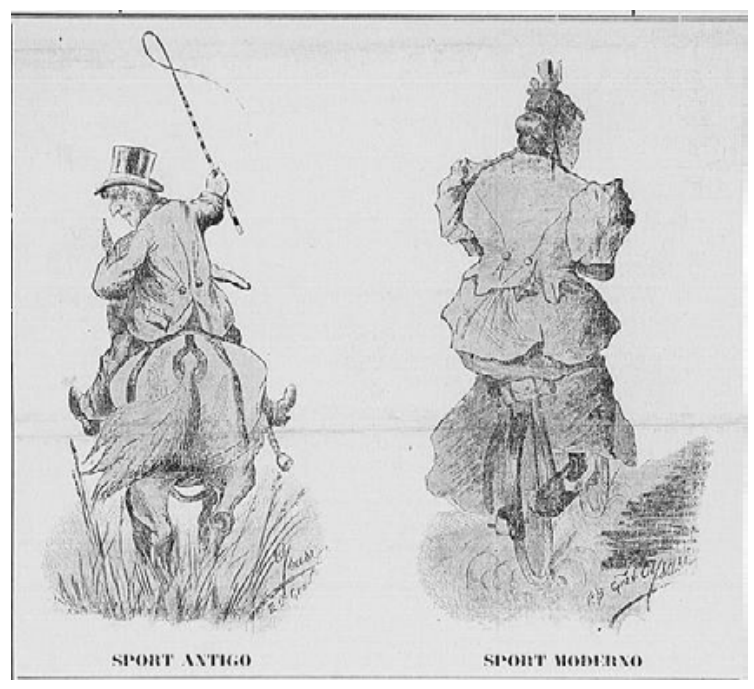

Fonte: Semana Sportiva, 2 dez. 1899, p. 1.

Essas diferenças, não poucas vezes, ocasionaram embates entre as lideranças esportivas, alguns deles publicados em Semana Sportiva. Ernesto Curvello Júnior, um dos mais importantes dirigentes do remo nacional, sugeriu que, no turfe, havia uma equipe formada por proprietário, jóquei, treinador e tratador, enquanto na modalidade náutica todos esses papéis eram desempenhados pelo remador, que, portanto, tinha que, no seu olhar, possuir conhecimentos superiores (Semana Sportiva, 15 dez. 1900, p. 2). O periódico não tomava partido. Encarava ambos como sinal de progresso e civilização.

Semana Sportiva, na verdade, propunha-se menos a ser um informativo de resultados ou um defensor das causas de clubes, frequentadores e coudelarias, como os outros periódicos citados. Era, todavia, ainda mais crítica no que tange ao grau de desenvolvimento do esporte nacional. Assim sendo, também buscou interferir na conformação do campo, sendo mais um dos agentes a estabelecer tensões naquele âmbito. Não surpreende que tenha em algumas ocasiões enfrentado o desgosto de alguns dirigentes. Da mesma forma, foram muitos os que a elogiaram e agradeceram pelos serviços prestados.

No que se refere a nosso tema de interesse, a circulação de ideias, o periódico apresentava algumas particularidades. $O$ exterior continuou sendo utilizado como parâmetro para julgar as peculiaridades do turfe nacional, entretanto, percebe-se maior reconhecimento dos limites de nossas agremiações, mesmo que em tom lamentoso. Pode-se notar essa perspectiva em um comentário sobre a iniciativa de alguns jóqueis brasileiros de criarem uma caixa de socorros mútuos.

Segundo o cronista, tratava-se de uma ideia "digna de todo aplauso de quem conhece a organização defeituosa do nosso turfe" (Semana Sportiva, 14 out. 1899, p. 1). Lembrava que, na Europa, a categoria era protegida por ação dos próprios clubes, mas, no Brasil, supostamente, esses "nada podem fazer atendendo a crise que estão atravessando". Tal deficiência era apontada como uma particularidade a ser superada.

Perceba-se que, na virada de séculos, a modalidade passou por dificuldades financeiras (MELO, 2001), mas mesmo nos momentos de maior prosperidade jamais se pensou em criar beneficios para os condutores de cavalos, em geral sempre muito vigiados, explorados e punidos até quando, claramente, não eram culpados. ${ }^{30}$ Para os cronistas de Semana Sportiva isso era 
uma expressão de que, ainda, preponderava uma mentalidade atrasada, expressão de nossos limites ao aderir à ideia de progresso.

Os cronistas de Semana Sportiva, ao tecer comparações com o que ocorria nos hipódromos pelo mundo, pareciam menos convencidos de que por aqui seria possivel adotar os mesmos procedimentos. A questão era buscar um caminho próprio a partir do reconhecimento das limitações nacionais: "à influência de nosso meio, unicamente, isso é, às condições atuais em que nos achamos, devemos atribuir essa agonia do turfe, sem necessidade de transplantarmos para aqui as causas predominantes que se observam no exterior" (Semana Sportiva, 3 mar. 1890, p. 1).

Esse olhar fica claro no posicionamento do periódico no que se refere ao uso de cavalos, que seguiam sendo importados da Inglaterra e da Argentina, em menor número da França. Se no passado, os cronistas defendiam esse procedimento como forma de garantir provas mais emocionantes e o desenvolvimento da raça equina nacional, em Semana Sportiva a sequência dessa estratégia era criticada. Para um jornalista, naquelas nações "o grande interesse despertado pelas corridas" devia-se ao fato de "que os páreos obedecem ao nacionalismo que nós não temos, porque, com certeza, aqueles países não abdicam de seu patriotismo para constituir páreos com animais estrangeiros" (Semana Sportiva, 3 mar. 1890, p. 1). Tratar-se-ia de definitivamente fazer esforços sérios para garantir condições adequadas para a criação de bucéfalos brasileiros de melhor qualidade.

Nesse sentido, usualmente considerava-se a Argentina como experiência exemplar que devia inspirar o que fazer no Brasil, ${ }^{31}$ uma mediação possivel entre o que ocorreu na Europa e pode ser reproduzido na América do Sul. No olhar de alguns cronistas, tendo como matriz o cenário inglês, os criadores platinos teriam conseguido criar uma raça de cavalos que, supostamente, seria mesmo superior à britânica. Isso seria responsável por hipódromos mais cheios em função das corridas emocionantes (Semana Sportiva, 25 nov. 1899, p. 1).

Há também que se ter em conta que foi um momento de maior aproximação entre Brasil e Argentina, marcado, entre outros, pela assinatura do Tratado de Fronteira (1898) e pelas visitas aos países dos presidentes Julio Roca e Campos Salles, uma proximidade que não durou muito tempo em função de discordâncias no âmbito das Forças Armadas e do comércio (CANDEAS, 2005).

Na recepção de Campos Salles em Buenos Aires, foram promovidos vários eventos esportivos - provas de remo, ciclismo e turfe - acompanhados amiúde pelos correspondentes de Semana Sportiva, notícias publicadas nas edições de novembro de 1900. O periódico agradeceu efusivamente aos argentinos pela gentileza e disponibilidade, celebrando os laços entre os dois países, dispondose a ser um elo de manutenção dessas relações (Semana Sportiva, 17 nov. 1900, p. 1).32

A despeito de termos em conta o momento político, note-se que sempre houve forte relação com o turfe argentino, ocorrência digna de nota por ser distinta do que tradicionalmente se aborda na relação centro-periferia. Em determinado momento, portanto, foi o país da América do Sul que mais parece ter inspirado o esporte hipico nacional, e não mais as referências que vinham diretamente do continente europeu.

No que tange aos contatos entre brasileiros e argentinos, no caso do remo havia uma particularidade a destacar. Como Semana Sportiva publicava noticias referentes ao Conselho Superior de Regatas, pode-se perceber a comunicação mantida com a Union de Regatas del Rio de la Plata, trocas de regulamentos, bem como propostas de provas em comum. Assim sendo, o periódico dava visibilidade a mais uma iniciativa de inserir o esporte nacional em um cenário mais amplo, antecipando ocorrências que

31 Em vários momentos da revista se percebe uma admiração pela capital da Argentina. Um cronista chegou a comentar: "Quem não se manifestará entusiasmado pelo progresso real e material de Buenos Aires? Os indiferentes ou os incrédulos" (Semana Sportiva, 24 nov. 1900, p. 2). Não cabe neste artigo um debate maior sobre o tema, mas vale considerar as contradições que a tornaram a primeira metrópole da América do Sul. Para mais informações, ver Coggiola (1997).

32 Ver também Semana Sportiva, 24 nov. 1900, p. 2 
se tornariam mais usuais na primeira década do século XX, quando as competições internacionais estariam melhor estruturadas. ${ }^{33}$

A propósito, o debate sobre o uso de produtos do exterior não se dava da mesma maneira no que tange às regatas. A discussão sobre a adoção de novas embarcações e promoção de páreos específicos tomou conta dos aficionados do remo na transição dos séculos. Como no turfe, o que ocorria no cenário mundial influenciava a discussão nacional, até mesmo porque as ligas fluminenses buscaram reconhecimento do órgão internacional da modalidade (MELO, 2001). Não surpreende, portanto, que o tema também estivesse presente nas páginas de Semana Sportiva. Os cronistas narravam os diversos pontos de vista, mas não se furtavam de comentar o que parecia o melhor caminho a seguir tendo em vista o desenvolvimento do esporte náutico brasileiro.

Os cronistas responsáveis pelo remo pareciam convencidos de que a qualidade dos barcos era um dos fatores que impedia o avanço da modalidade no Rio de Janeiro. Enquanto as provas no Brasil ainda eram majoritariamente disputadas com pesadas baleeiras, na França, nos Estados Unidos e na Inglaterra já eram utilizadas embarcações mais leves e com inovações que permitiam performance superior. Para eles, esses eram os modelos a serem adotados, e como os construtores nacionais não conseguiam fabricálos, seria necessário importar (Semana Sportiva, 10 nov. 1890, p. 2), algo que já se mostrara eficaz em função de alguns yoles, outriggers e skiffs que certos clubes possuiam. ${ }^{34}$

A posição dos cronistas de turfe e de remo pode, a principio, parecer diametral, mas guarda semelhanças. Frente às limitações da economia nacional, ambos procuravam ser pragmáticos. Para o jornalista do esporte hípico, modalidade que vinha se estruturando há mais tempo, não dava mais para seguir com antigas estratégias, devendose investir definitivamente em uma solução caseira.
Já para o narrador do esporte náutico, ainda tardaria muito para termos uma indústria brasileira que desse conta do esperado, devendo-se, portanto, adotar uma saída imediata: a importação.

Ambos, de alguma maneira, repercutiam uma questão nacional candente: como o Brasil faria parte do grande concerto internacional no âmbito da $2 .^{a}$ onda de globalização e de revolução industrial, os limites que se apresentavam para nossa adesão a parâmetros de modernidade. Não somente na economia, como também na política e na cultura, sentiu-se a necessidade de novos caminhos. Como sugere Schwarcz (2012, p. 29), progressivamente a ideia de "somos da América, mas queremos ser europeus" foi sendo substituida pela de "somos da América e queremos ser americanos".

Nem todos concordavam com as posições dos cronistas. Ernesto Curvello Júnior escreveu à revista sugerindo que a indústria brasileira poderia, sim, prover as agremiações náuticas de material adequado. Mais ainda, a seu ver, os construtores fluminenses sabiam que "o nosso esporte tem muita particularidade, a par da remada e da percepção da medalha" (Semana Sportiva, 15 dez. 1900, p. 2). Entre outras coisas, em algumas ocasiões se argumentou que as águas da Baía de Guanabara tinham peculiaridades que deveriam ser consideradas.

A resposta do cronista da Semana Sportiva referendou o olhar do periódico: "Não pomos em dúvida a possibilidade da boa construção em nosso país. Julgamos mesmo que aqui se poderá fazer tão bem como no estrangeiro. Isso, porém, depois de experiências e estudos que consumirão tempo e dinheiro aos clubes [...]" (Semana Sportiva, 24 nov. 1900, p. 2). Tratava-se de uma posição mais pragmática. O desenvolvimento do esporte não poderia esperar a superação de nossos problemas estruturais, sendo concebido mesmo como estímulo para tal.

Esses limites tecnológicos eram também abordados no que tange à velocipedia (ciclismo).

\footnotetext{
33 Há que se citar que, naquele fim de século, alguns clubes de Porto Alegre já participavam de competições no Uruguai e na Argentina Um indício interessante é o envolvimento desses remadores nas citadas provas náuticas promovidas em Buenos Aires para homenagear Campos Salles (Semana Sportiva, 1 set. 1900, p. 2)

34 Para uma breve história do uso de embarcações no remo fluminense, ver Semana Sportiva, 20 out. 1900, p. 3. Deve-se destacar que muitos clubes também importavam da Europa as vestimentas para remar. Ver Semana Sportiva, 15 dez. 1900, p. 2
} 
Bicicletas ainda eram uma novidade no Brasil, sua importação e manutenção eram custosas. Em algumas ocasiões, o periódico chamou atenção para que se estimulasse o seu uso e aquisição, considerando o impacto que o artefato teve em algumas cidades. Para um cronista, poderia também, no Rio de Janeiro, "desempenhar um papel proeminente, para além de simples esporte, o que tem, aliás, acontecido nos principais países da Europa e da América" (Semana Sportiva, 8 set. 1900, p. 2).

Em Semana Sportiva, as representações positivas da bicicleta ficavam claras até mesmo em algumas propagandas. Uma das mais notáveis era a da Monarch, claramente inspirada nos reclames que circulavam na França (Imagem 5). A imagem de uma mulher bem trajada, debruçada no seu "cavalo de ferro" a olhar um mapa, era uma expressão de novos ventos de protagonismo feminino que chegavam do continente europeu. ${ }^{35}$

Imagem 5 - Anúncio da bicicleta Monarch

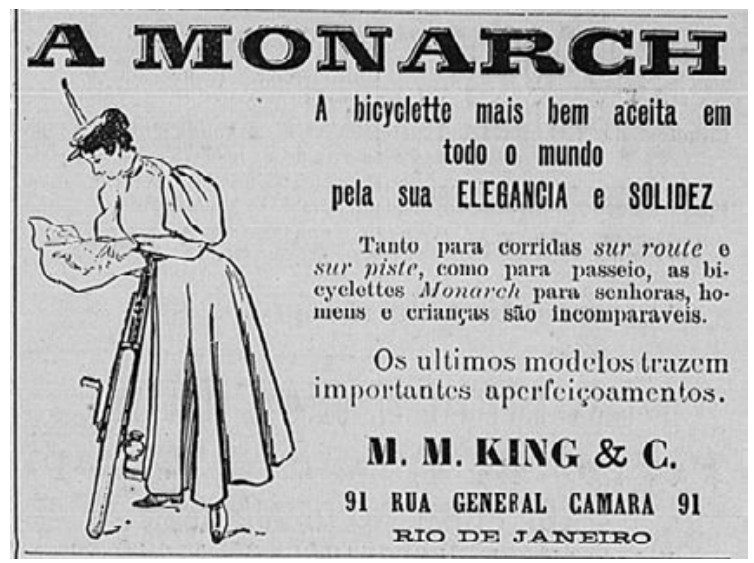

Fonte: Semana Sportiva, 24 fev. 1900, p. 3

O lema de A Monarch, bem poderia ser uma parábola do que desejava Semana Sportiva: "A bicicleta mais bem aceita em todo o mundo pela sua elegância e solidez". Os cronistas esperavam que o esporte brasileiro se consolidasse à altura das melhores experiências internacionais. Para tal, vislumbravam um processo que melhor considerasse nossas peculiaridades. Reconheciam nossas limitações e sugeriam saidas imediatas e pragmáticas.

\section{Considerações finaîs}

Em função das restrições de acesso aos periódicos esportivos, é forçoso reconhecer os limites de nossa investigação. Ainda assim, o consultado pareceu-nos suficiente para permitir discutir o tema que nos interessou neste artigo: a circulação de ideias

Sendo o esporte uma prática transnacional que chegou ao Brasil a partir de influências britânicas, bem como de relatos sobre o que ocorria em outros países, não surpreende que a imprensa fluminense, aqui investigada no que tange aos periódicos específicos, tenha promovido uma intensa circulação de ideias, na esteira de uma também intensa movimentação de cavalos, barcos, bicicletas e jóqueis. Nos veículos consultados, percebe-se, todavia, diferenças de perfil no diálogo estabelecido com referências do exterior, algo que teve relação com mudanças no contexto e no padrão de jornais e revistas.

Em um primeiro momento, quando o País passava por uma crise na experiência monárquica, mas ainda mantinha certos parâmetros culturais do período, bem como a imprensa dava os primeiros passos no sentido de se modernizar, as referências ao exterior - especialmente à Inglaterra e à França - eram encaradas como modelos a serem adotados para o desenvolvimento do campo esportivo nacional. Parecia, ainda, imperar a ideia de que deveriamos constituir um projeto civilizacional à moda de certas nações europeias.

Os cronistas se propunham a ser defensores de clubes, frequentadores ou coudelarias, sendo as informações veiculadas também de caráter mais descritivo. O turfe era praticamente a única modalidade abordada, o que se entende tanto pela popularidade angariada pelas corridas de cavalos na transição das décadas de 1880-1890 quanto pelo fato de que outros esportes ainda davam passos tímidos.

Em um segundo momento, tendo como exemplo um periódico de maior alcance e longevidade, a Semana Sportiva, ampliou-se o número de modalidades abordadas, bem como 
adotou-se um caráter mais crítico, ainda que menos vinculado a grupos específicos. A revista era uma expressão de uma imprensa que se aperfeiçoara e multiplicara os títulos.

O país começava a consolidar sua experiência republicana, depois de uma série de conflitos nos anos iniciais da década de 1890. Se ainda tinha referências europeias como parâmetros, já procurava trilhar caminhos mais próprios. Nas revistas, as ideias sobre o esporte no exterior seguiram sendo apresentadas como exemplos, mas já com sugestões de ajuste às peculiaridades da sociedade nacional e do campo esportivo no Brasil organizado.

Merece destaque que, nesse periódico, grande atenção tenha sido dada ao que ocorria na Argentina, cuja capital Buenos Aires era admirada pelos cronistas. A experiência do vizinho da América do Sul foi encarada como uma prova de que o Brasil tinha condições de reproduzir com particularidades o que houvera na Europa, podendo até mesmo superar aquilo que ocorrera na Inglaterra e na França. Esse interesse pelo Rio da Prata, de alguma forma, também se relacionava com o que se passava no âmbito da política externa brasileira.

Os periódicos dedicados ao esporte atuaram, portanto, em consonância com os movimentos da imprensa e da sociedade nacionais. Personagens fundamentais na conformação do campo esportivo, funcionando como agência mediadora, a análise desse material nos permitiu observar o cenário em que foram publicados, nos ajudando a lançar um olhar sobre nosso processo de adesão ao ideário e imaginário da modernidade, estratégias e representações forjadas a partir de considerações sobre nossos limites econômicos e culturais.

\section{Referências}

ARCHETTI, Eduardo. Masculinidades. Fútbol, tango y polo en la Argentina. Buenos Aires: Antropofagia, 2003.

BARBOSA, Marialva. História cultural da imprensa: Brasil. 1800-1900. Rio de Janeiro: Mauad X, 2010.

CANCLINI, Néstor Garcia. Culturas hibridas: estratégias para entrar e sair da modernidade. São Paulo: Edusp, 1997.
CANDEAS, Alessandro Warley. Relações Brasil-Argentina: uma análise dos avanços e recuos. Revista Brasileira de Politica Internacional, Brasilia, v. 48, n. 1, p. 178-213, jun. 2005. https://doi.org/10.1590/So034Z3292005000100007.

COGGIOLA, Osvaldo. Buenos Aires, cidade, política, cultura. Revista Brasileira de História, São Paulo, v. 17, n. 34, p. 101-118, 1997. https://doi.org/10.1590/S010201881997000200005

FERREIRA, Tânia Maria Tavares Bessone da Cruz. Comércio de livros: livreiros, livrarias e impressos. Escritos (Fundação Casa de Rui Barbosa), Rio de Janeiro, n. 5 , p. 41-52, 2011

GAMARNIK, Cora. La fotografía en la revista Caras y Caretas en Argentina (1898-1939): innovaciones técnicas, profesionalización e imágenes de actualidad. Estudos Ibero-Americanos, Porto Alegre, v. 44, n. 1, p. 120-137, jan./abr. 2018. https://doi.org/10.15448/ 1980-864X.2018.1.27391.

HARVEY, Adrian. The beginnings of a commercial sporting culture in Britain, 1793-1850. Abingdon: Ashgate Publishing, 2013

HOLT, Richard. 1989. Sport and the British: a modern history. New York, Oxford University Press.

HORA, Roy. Historia del turf argentino. Buenos Aires: Siglo XXI Editores, 2014

MAIA, João Marcelo E. Costa Pinto em dois tempos: os efeitos periféricos na circulação de ideias. Tempo Social, São Paulo, v. 31, n. 2, p. 173-198, 2019. https:// doi.org/10.11606/0103-2070.ts.2019.148331.

MARTINS, Ana Luiza. Revistas em revista. São Paulo: EDUSP, 2001.

MARTINS, Ana Luiza; LUCA, Tania Regina (orgs.). História da imprensa no Brasil. São Paulo: Contexto, 2008.

MAUAD, Ana Maria. Na mira do olhar: um exercício de análise da fotografia nas revistas ilustradas cariocas, na primeira metade do século XX. Anais do Museu Paulista, São Paulo, v. 13, n. 1, p. 133-174. jan.-jun. 2005. https://doi.org/10.1590/S0101-47142005000100005.

MELO, Victor Andrade de. Cidade sportiva: primórdios do esporte no Rio de Janeiro. Rio de Janeiro: Relume Dumará/Faperj, 2001

MELO, Victor Andrade de. Causa e consequência: esporte e imprensa no Rio de Janeiro do século XIX e década inicial do século XX. In: HOLLANDA, Bernardo Borges de; MELO, Victor de Andrade (org.). O esporte na imprensa e a imprensa esportiva no Brasil. Rio de Janeiro: 7 Letras, 2012. p. 21-51.

MELO, Victor Andrade. As touradas nas festividades reais do Rio de Janeiro Colonial. Horizontes Antropológicos, Porto Alegre, v. 19, n. 40, p. 365-392, 2013. https:// doi.org/10.1590/S0104-71832013000200014.

MELO, Victor Andrade. Antes do club: as primeiras experiências esportivas na capital do Império (18251851). Projeto História, São Paulo, n. 49, p. 197-236, 2014. 
MELO, Victor Andrade. "Pois temos touros?": as touradas no Rio de Janeiro do século XIX (1840-1852). Análise Social, Lisboa, v. 50, n. 215, p. 382-404, 2015.

MELO, Victor Andrade de. Mudanças nos padrões de sociabilidade e diversão: o jogo da bola no Rio de Janeiro (séculos XVIII e XIX). História, São Paulo, v. 35 , n. 105, p. 1-23, 2016. https://doi.org/10.1590/1980436920160000000105

MELO, Victor Andrade de. A sociabilidade britânica no Rio de Janeiro do século XIX: os clubes de cricket. Almanack, Guarulhos, n. 16, p. 168-205, ago. 2017. https:// doi.org/10.1590/2236-463320171604.

MELO, Victor Andrade de: PERES, Fabio de Faria. Primórdios do esporte no Brasil. - Rio de Jjaneiro: Reggo Edições, 2016.

MELO, Victor Andrade de; SCHETINO, André. A bicicleta, o ciclismo e as mulheres na transição dos séculos XIX e XX. Estudos Feministas, Florianópolis, v. 17, n. 1, p. 111-134, abr. 2009. https://doi.org/10.1590/S0104026X2009000100007.

NEEDELL, Jeffrey D. Belle Époque tropical. São Paulo: Companhia das Letras, 1993.

VELLOSO, Monica Pimenta. Percepções do moderno: as revistas do Rio de Janeiro. In: NEVES, Lúcia Maria Bastos P.; MOREL, Marco; FERREIRA, Tânia Maria Bessone da C. (org.). História e imprensa: representações culturais e práticas de poder. Rio de Janeiro: DP\&A/ Faperj, 2006. p. 312-331.

SANTOS, João Manuel Casquinha Malaia. Economia do Entretenimento: o processo de monopolização do primeiro empreendimento esportivo no Brasil (1850-1930). Economia e Desenvolvimento, Santa Maria, v. 27, n. 1, p. 202 - 222, jan./jul. 2015. https://doi. org/10.5902/1414650919167.

SANTOS, João Manuel Casquinha Malaia; GIGLIO, Sérgio Settani. O papel da memória na construção da identidade organizacional: a Sociedade Jockey Club (1868-1932) e o "desenvolvimento da riqueza pastoril". Recorde: Revista de História do Esporte, Rio de Janeiro, V. 10, n. 1, p. 1-21, jan./jun. 2017

SCHETINO, André. Pedalando na modernidade: a bicicleta e o ciclismo na transição dos séculos XIX e XX. Rio de Janeiro: Apicuri, 2008.

SCHWARCZ, Lilia Moritz. As barbas do Imperador. São Paulo: Companhia das Letras, 1998.

SCHWARCZ, Lilia Moritz. As marcas do periodo. In: SCHWARCZ, Lilia Moritz (coord.). História do Brasil Nação (1808-2010): volume 3 - A abertura para o mundo (1889-1930). Rio de Janeiro: Objetiva, 2012. p. 19-34.

SILVA, Maria Beatriz Nizza da. A Gazeta do Rio de Janeiro (1808-1822): cultura e sociedade. Rio de Janeiro: Eduerj, 2007.

\section{Victor Andrade de Melo}

Estudos de Pós-Doutorado em História pela Universidade Federal Fluminense (UFF, Niterói, RJ, Brasil), professor titular da Universidade Federal do Rio de Janeiro (UFRJ), RJ, Brasil.

\section{Endereço para correspondencia}

Victor Andrade de Melo

Universidade Federal do Rio de Janeiro

Programa de Pós-Graduação em História Comparada - PPGHC/UFRJ

Largo de São Francisco de Paula, n. 1, sala 311

Centro, 20051-070

Rio de Janeiro, RJ, Brasil 